\title{
剔脾により治癒せる特發性栓球減少性紫斑病の3 例
} 特に催栓球減少性因子と剔脾前後の巨核球の機能に就いて

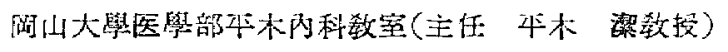 \\ 小林正, 角南宏, 粟井弘二 \\ THREE CASES OF IDIOPATHIC THROMBOCYTOPENIC PURPURA CURED \\ BY SPLENECTOMY - ESPECIALLY ON THE PLATELET REDUCING \\ FACTOR AND FUNCTION OF THE MEGAKARYOCYTE \\ BEFORE AND AFTER SPLENECTOMY
}

By

Tadashi Kobayashi, Hiroshi Sunami and Kôzi Awai

Department of Internal Medicine, Okayama University, School of Medicine

(Director: Prof. Kiyoshi Hiraki)

We have had recently three cases of the chronic type of idiopathic thrombocytopenic purpura. All of the cases showed remarkable increase of platelets by splenectomy. The genesis of this disease researched, the existence of platelet reducing factor was found in patients sera and extracts of the spleen. And yet it was made sure through bone marrow streaming examination for this factor to act directly upon the bone marrow.

This factor transfered into the cerebrospinal liquor and was secreted in the urine. Moreover, the function (movement and platlet production) of the Megakaryocyte was observed by tissue culture of patients bone marrow and taken microcinematograms in success. The number of the megakaryocytes decreased in two cases and increased in one case of the three compared with normal.

Most of them had neither motility nor tentacle-like filament in spite of their maturity, and thus showed a severe hypofunction. The number of the megakaryocytes after splenectomy in all cases recovered to the normal.

They stretched out many strange and complicated pseudopodia in all direction, and showed vigorous migration as well as striking formation of tentacle-like filament.

A phenomenon of platlet separation was sometimes observed at the top of their filament.

From above-mentioned findings, the followings could be considered; The splenectomy on the patients with chronic idiopathic thrombocytopenic purpura resulted in disappearance of the splenogenic toxic substance and immediate recovery of both function and number of the megakaryocytes by elimination of the disturbance of their development and production.

It is concluded that the genesis of chronic idiopathic thrombocytopenic purpura mainly exists in the hypofunction of the megakaryocytes. 


\section{緒䨐}

特發性栓球娍少性紫班病は 1738年 Werlhof に より初加て獨立疾患として記載せられ，1915年 Frank により Die essentielle Thrombopenie $と$ 合名された．Kaznelson(1916)は本症に剔脾が有 效であり，特に慢性例に於いてはその效果は全く 鹤的であると報告した，本症の病因に就いては，令 日尚, 不明であるが，Kaznelson の脾欌に於ける

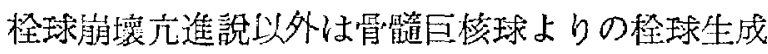
障害にその原因を求めんとする Frank の考えが 有力である. Troland and Lee (1938), Ungar (1945)等は脾藏に於いて骨随白核球の機能抑制物 浜が産生されると考えた。最近 Dameshek(1953) は免疫血液學の立場より，栓球凝集素分直接に末

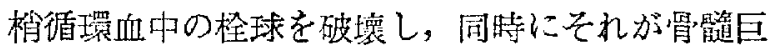
椟球に作用して栓球生成を抑制するものであると 主張した.

最近われわれは特發性栓球減少性紫斑病の慢性 型 3 例を經酸し，剔脾を中心としてその前後の臨 环經過を觀祭する機會を得たので，その售程球減 少性因子を追求し，その直接骨膃に及ほす作用を

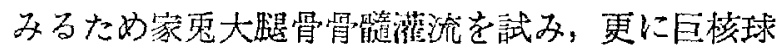
の機能を組織培䥅法にて研究し, 初めてその霹足 運動及び栓球分離像の映畫撮影に成功する等，い さつか新知見を得たのでこつに報告し諸蘋の御批 制を仰ぐ次第である。

\section{踽床 例}

第 1 例

45才，女，會社員

笪病：昭和24年，何等誘因と思われるものなく 皮下出血を來たすを，之の後輕快。沿和28年10月 皮下出血斑再び現れ，同時に鼻・腔内出血續き， 12月5日蝴絧膜下出血を來たして16日り人 院す. 入院洔血液像で法出血性貧血あり，栓球数

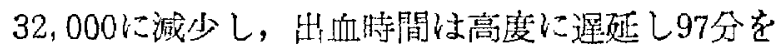
示す. 入院後活 A C T H $340 \mathrm{mg}$ 使用し出血時間 の短綰と柽球教の増加を認めたので，この機を㨡 えて剔脾手術を行なつた。術後栓球數は第 1 圖の 如く急速に堌加し30日目で正常値に達した。骨”䒃

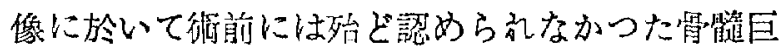

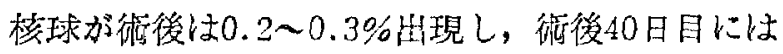

第 1 圆 患者栓球敦推移

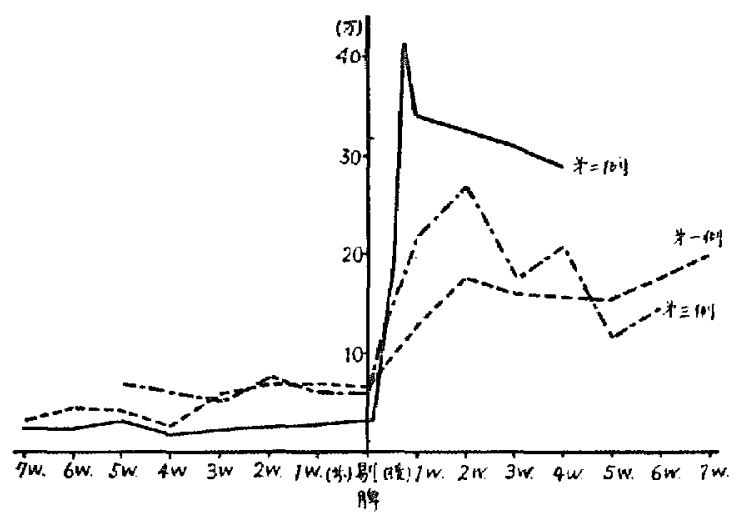

血液像もすべて正常となり4月28日全治退院す。

第 2 例 39 才, 女, 農業

發病：昭和24年，月經時に皮下出血斑を來たす と共に經血量もや〉多く，その後もからる狀態を 嘪计，昭和29年 3 月頃上り月經過多强度となり，月

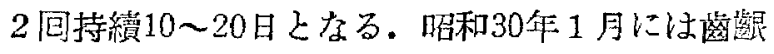
出血と兩下肢に多數の出血班を諗む４月15日月 經終了後, 全身に点爿出血斑を來たし，5月 6 月 多量の性器出血あり口に入院す，大院時血液像 では柽球數 22,000 に減少し, 出血時間49分京

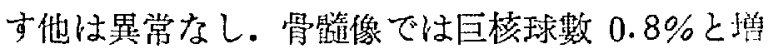

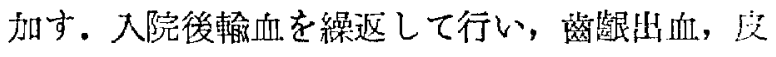
下出血共に消失したので，月經休止期に剔脾を行 う. 逨後 4 日目に柽球數は 420,000 に達し, 後次 第に正常値に加える. 巨核球數は術後 $0.1 \%$ 以下 となつな７月27日全治退院す。

第3 例口 58才，女，露業

發病：昭和21年 2 月，誘因なく血健を來たし約 1 力月の治療により治康した。，その後, 時に輕度

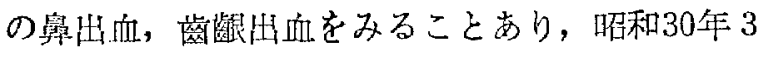

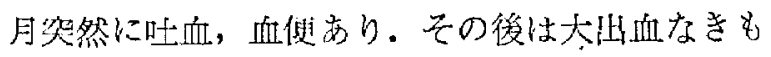

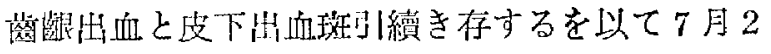
日大院す。入院特所見として所 3 横指, 脾 3 横指 を触れ，血液像では柽球數 62,000 に減少，出血 時開17分を示す. 8 月 6 日剔脾手術を行うに，迴 後より柽球數は增加し2 週後267,000 に達した。 その後出血傾向全くなく10月7日治瘾退院す。 倠栓球減少性因子の存在に就いて 
本症患者血清及び睡浸出液中の毒性物䝷師方栓 球減少性因子の存在に就いては Toland and Lee, Harrington, Stefanini, 奥田, 平岡等の報告に見 られる所であるが，われわれも本症患者血清, 脾 リンぶル・アセトン浸出液更に腦春䯕液及び尿中 にも本因子の存在を証明することが出來た。

實驗動物は $2 \mathrm{~kg}$ 前後の白色雄性家鬼を用い患者 䄪料はすへて皮下注射した。栓球算定法は Fonio 氏法に準し，手技を一定にするため，Hb 測定用 ピペッにて硫酸マグネシヤ液との比率を一定に し時計四上にて混合し塗抹後, 速かに乾燥固定し た.

イ）患者血清注射の場合

剔脾前後の患者血清 pro $\mathrm{kg} 2 \mathrm{cc}$ 注射するに第 2 圖に示す如く剔脾前血清注射の場合, 栓球の最

第 2 圖 剔䐬前後患者血清注射による栓球数 (pro kg 2 cc 度下)

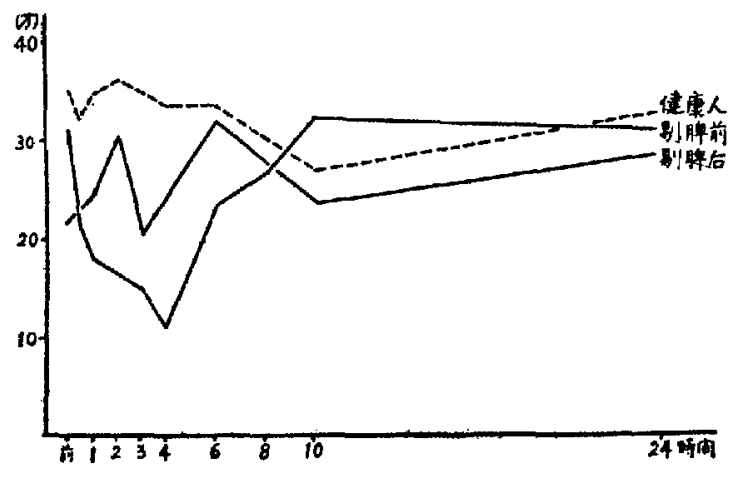

大減少率一 $67 \%$ で著明に減少し，剔脾後血清注射 に於いてはー17\%を示したに過ぎず生理的動摇範 圍であつた．以上の事實より本症原因の一端が脾 内に存することを窺いうる。同樣に以下の實驗を 試なた。

ロ）脾 $5 \%$ リン゙ル浸出液注射の場合

患者剔出脾 $5 \%$ リンゲル漫出液 pro kg $2 \mathrm{cc}$ 家 鬼へ皮下注射するに第 3 圖の如く栓球娍少率は -88\%，一72\% と著明なる低下を示した。份, 對照 には胃潰場，日本腦炎剖檢例の脾澸を用いたが何 れも 10\%前後の程度の娍少を示したのみである.

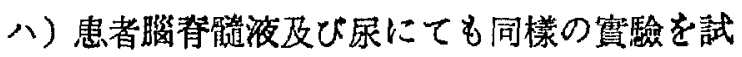

第 3 圆 $5 \%$ 脾 リングル浸出液注射による栓球數 (Pro kg 2 ce 使下)

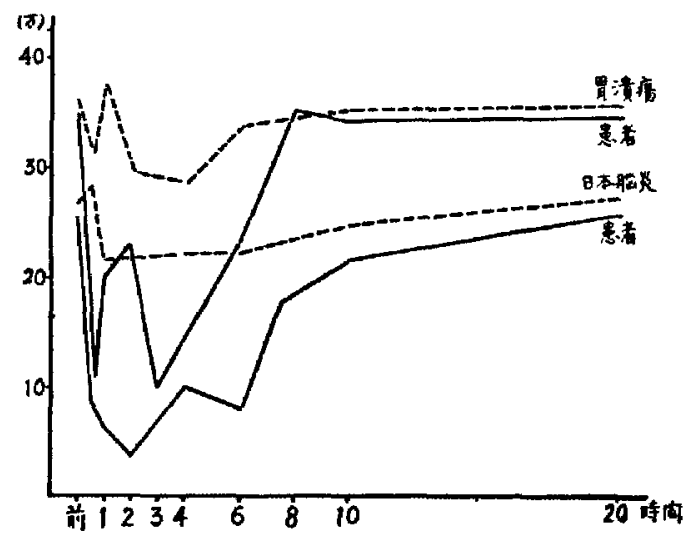

み，本因子の春䯣液及び尿への移行，排泄を認め 得た. 又 Troland の行なつた如く脾荿アセトン 浸出液にても彼同榜本因子を証明することが出來 た。

二）骨䯠淮流實驗

1932年 Gerlach は本症の原因は栓球の動員機 構の抑制であるとなし，1946年 Dameshek and Miller は骨䯕巨核球よりの栓球生成減少と同時 に栓球の流血中への動員障害であるとなしている が，われわれの行なつた實驗結果も彼等の說を裹 付ける如きものであつた。師方患者血清 $0.1 \mathrm{cc} に$

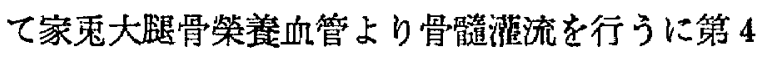
圖の如く榮養静脈にて栓球数一87\%の減少を來た した.この事實より患者血清中に含まれる催栓球 減少性因子は直接に骨䯣に働き，程球の流血中一 の遊出を抑制するものと推定される。

こっに於いてわれわれは更に骨䭪組織培養にて 骨髓巨核球の機能を觀察した。

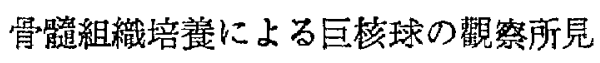

培養法 : 胸骨骨髓察刺によつて得られた組織片 を海野氏載物硝子を用いて被覆培善を行い，骨败道 巨核球の運動能を中心として觀察した。尚，同時 に墨粒貪嗆試驗をも試みた。

\section{第 1 例 (}

入院時胸骨骨眭組織培荃では培盖標本 4 枚中原 組織に接近して 2 個の成熟巨核球を認めた。細胞

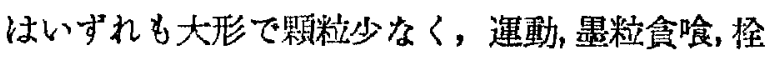


筙 4 圆 榮盖靜脈の栓球数

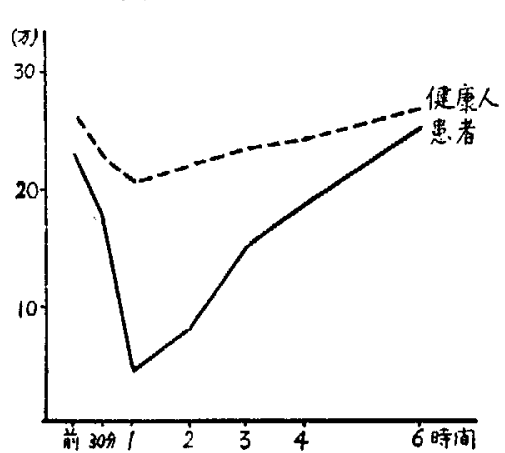

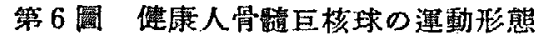
(突起形成)

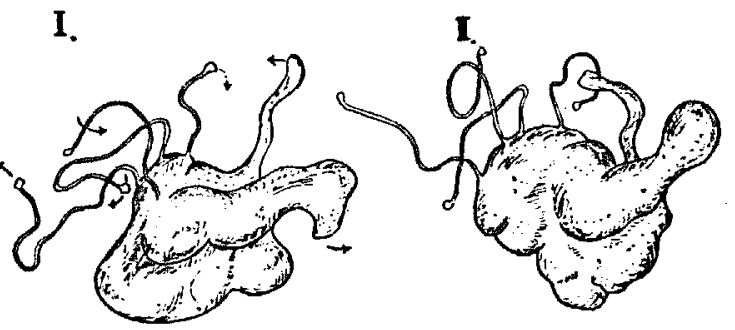

第 5 國 健康人骨瞇巨核球の運動形態(傜足運動)

I.

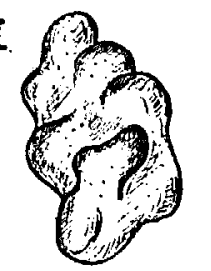

I.
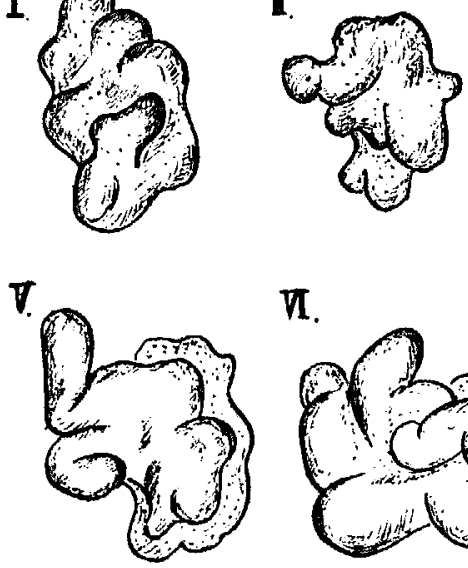

I.

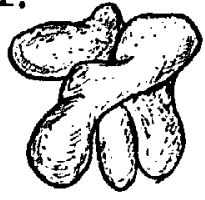

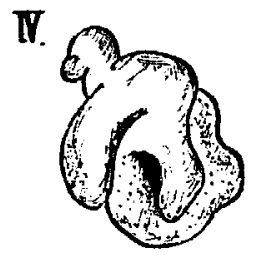

VII.

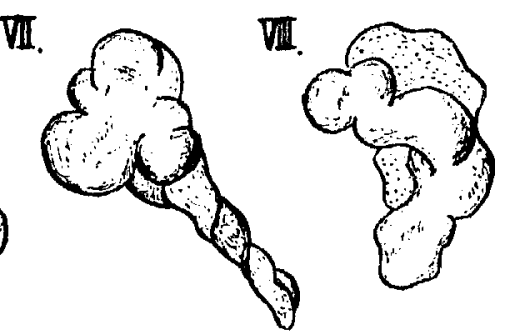

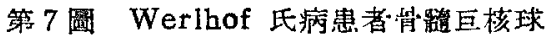
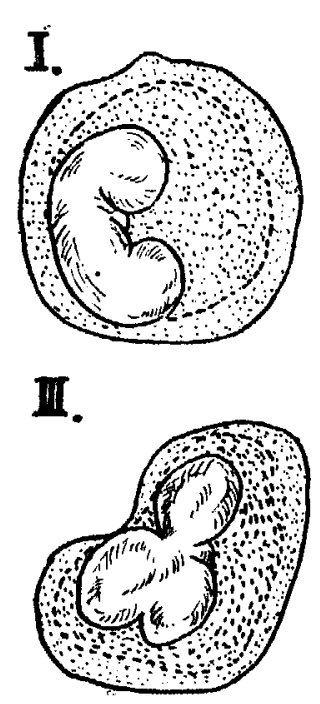

II.

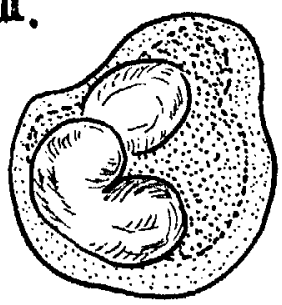

IT.

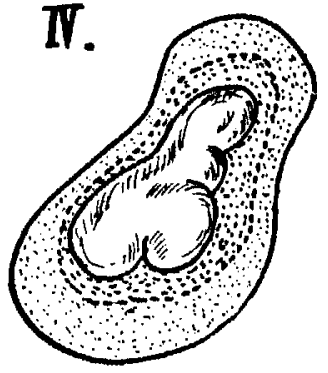

第 8 圆 Werlhof 氏病患者(剔䛲術後) 角䯈巨核球 第 1 症例

I.

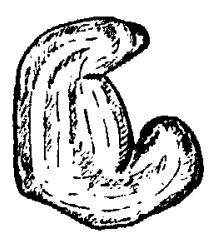

$\mathbf{x}$

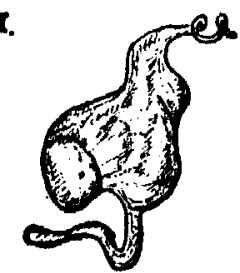

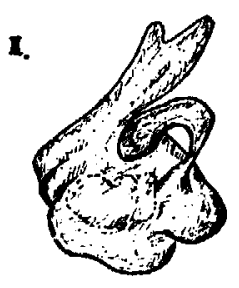

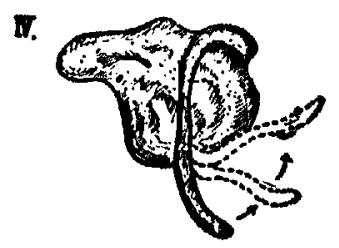


球形成を見ない(第 7 圖).剔脾後50日目の組織培 㟤では，培養後 4 時間目にして 1 枚の標本に 1 2 個の巨核球出現し，第 8 圖に示す如き哸足運動 をなして原形を留めぬ迄の戀形を認めた。更に幅 $2 \sim 3 \mu$, 長さ $60 \mu$ に達する突起を $1 \sim 2$ 本出して コブラの頭の如くに速かに上下左右に振り動かす のを認めた。此の突起の内部には顆粒の流動あ り，時としては2〜3 包捻れて結節形成を示すも のも西る．墨粒貪哴能なく，栓球分離像は直接認 め得なかつた。

第 2 例 ( )

剔聘前後におのおの 3 包宛, 計 6 回の胸骨穿刺 を行い，組織培養にて巨核球を觀察した。

剔脾前；25枚の培盖標本を作り，その内12枚に はA CTHのリンゲル稀䆁液を添加した。健康人 骨䯕組織培着では 1 標本中に遊出する巨核球數は 大約 $1 \sim 5$ 個であるが，本例では 1 標本中に出現 する巨核球數は平均 13.2 個の高值を示した。運動 を示すものは僅かに 5.9\%に過ぎず（健康人では 30〜80\%), 大多數の巨核球は解鋭なる境界を有す る殆ど正圓形の細胞として認められるのみで，僅 かに運動を示すものも第 7 圖に示す如き極めて緩 慢な胞体の變形運動が最大限で，通常僅かに棈圓 形乃至不正圆形を示すに止まる，健康人に見られ る如き著明な啋足形成，位置移動等は全く見られ ない。

A C T H添加により標本中に出現する巨核球數 は平均 9.8個となり，前者に比して幾分減少する が，運動形態を示しているものは10.2\%と多少増 加の傾向あり.此の事實は術前患者にA C T Hを 投與すると一過性乍ら顯著な栓球數堌加が起こる 事と何等かの關連を有するであろう.

剔脾後；術後 1 週， 2 週， 4 週の計 3 回にわた り，毎回約20枚の培盖標本を作製し，各回共にそ

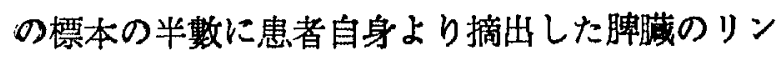
ゲル抽出液を添加して觀察した。

無添加標本に於いては 1 標本中に出現する巨核 球數は第 1 回及び第 2 回培養に於いて術前のそれ 上り遥に少なく，それぞれ 6 個，4個となつてい
る. 又出現した巨核球のうち運動形態を示すもの は，3回の培盖を通して培盖後10～15時間の平均 值は最低 $14.3 \%$ ，最高 $26.3 \%$ で術前の $5.9 \%$ に比 し著しい差異が認められる．その運動は健康人巨 核球で見られる猵足運動と同程度のもので，更に われわれは本例の巨核球が細長い㔖起形成をなし 極端に活潑な運動を行うのを觀察した。師ち剔脾 後 1 週目の培亘標本中に第 9 圖に示す如く幅 1 $2 \mu$, 長さ $10 \sim 40 \mu$ 細長い觸手狀㔖起數本を有 する巨核球を發見した。この突起の中，あるもの は先端部乃至は中途の部分が膨大して球狀部を形 成す。この球狀膨大部は一見栓球樣で，この部と 突起の移行部には强いくびれを生してて，時に栓球 分離像を認めることあり。かっる突起形成は健康 人巨核球では稀にしか見られないものである。

第 9 圖 Werlhof 氏病患者(剔脾街後) 骨制巨核球 第 2 症例

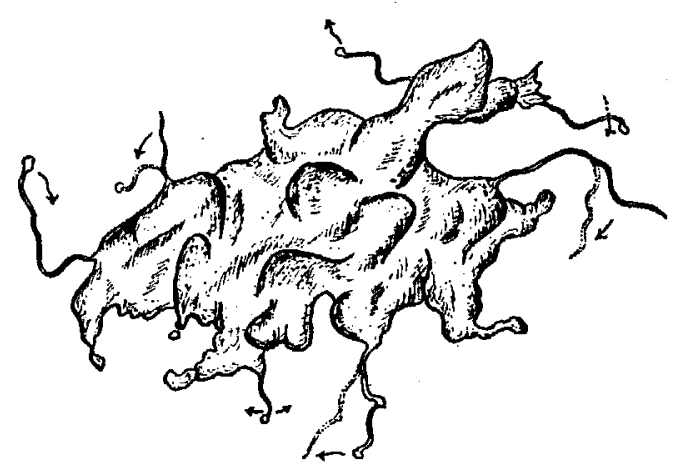

脾抽出液を添加した標本では遊出巨核球數は一 般に無添加標本群のそれより増加の傾向を示し た.更に運動能あるものは 3 回の培盖を通じて, 培僐後10〜15時間の平均值で最低 $3.3 \%$ 最高 12.3 \%を示し, 明らかに無添加標本群のそれより減少 している. 此の實驗の結果，本症患者脾抽出液 中には巨核球の運動能を減弱せしめ，更にその巨 核球數を增加する因子が存在するものと考えられ る.

第 3 例

剔脾前 1 司, 後 2 回計 3 国の胸骨骨跣案刺によ り前 2 例と同樣の方法にて約40枚の培養標本を作 制して觀祭した．培着標本中に出現する巨核球數 
は衡前に於いては平均 1.1 個で正常値に比し稍と 減少を示すも，術後は 2.7 個で正常化の傾向を示 した。運動形態を示すものは術前に於いては皆無 に近く, 術後は平均 $51.4 \%$ の高率を示した. 然し その運動は健康人巨核球と同程度で第 2 例の如き 觸手狀乫起形成を認め得なかつた。

\section{考按}

本症の成因として脾荿の病的機能により栓球减 少を招來することは，本症に剔脾が有効な事から 全く議論の餘地がない. 然し柽球減少の發生機序 に關しては諸說紛々として未だ一致を見ない。 Frank(1915) は本症の成因を脾茙より産生せられ る或る因子の作用により，巨核球の栓球形成障害 を來たした篇と主張した。一方 Kaznelson(1916) は脾臓の異常な栓球崩壊作用にその原因を求めて いる.その後，數多くの研究者により Frank の 說が支持された。最近 Stefanini, Dameshek 等 （1953）は本症慢性型で剔脾無效例を報告し，そ の成因を免疫血液學の見地より，患者血清中に証 明された栓球凝集素によつて直接末梢血中の破壞 と，骨䯕巨核球の栓球生成障害を來たしたもので あろうと推定している．以下われわれの系統的に 行なつた各種實驗成績より文献的考察を加え乍ら 本症の成因を追求せんと試みるものである。

先ず本症骨髓像並びに骨䯕組織培盖に於ける巨 核球數の增减を健康人のそれと比較するに第 1 例 及び第 3 例は減少，第 2 例は増加を示した。現在 迄の諸家の報告によれば， Seelinger (1924) よ り Pisciotta, Stefanini and Dameshek (1953) に至る迄，増加を認めたものが圧倒的に多い。 然し正常乃至減少も少數例であるが，存在する (Lawrence and Knutti, 䕐井等)。われわれの例 では 1 例は増加，2 例は減少せるも剔脾後は 3 例 そもに正常化の傾向を示した。

次に脾内に産生せられた催栓球娍少性因子の問 題であるが，Frankの說を寒付けるものとして， 1938 年 Troland and Lee に始まり Hobson (1940), Ostanasek (1941), Harrington et al (1951),さらに本邦に於いては奥田（1952）, 平凧
（1953)等の報告が見られ，われわれの實驗に於い てもその毒性物質が確認された．更に一歩進めて

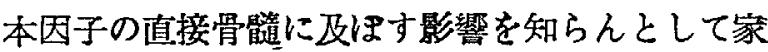

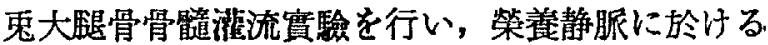
栓球の著明な減少を認めた，然し乍らここ迄の 實驗成績では，果して本物質が直接巨核球に作用 するのか, それとも Gerlach(1932)の唱える栓球 動員機構の障害を來たしたに過ぎないのか，決定 し得ないので更に組織培盖による巨核球の動態觀 察を試みた。

本症に於ける骨䯠巨核球の形態學的研究は Frank, Seelingerが初めてその異常なる事を報告

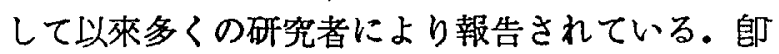
ち栓球生成像の減少と共に潹刻なる成熟障害を認 める Rohr (1934), Heilmyer (1951), Dameshek: and Miller (1946), Pisciotta, Stefanini and Dameshek （1953）等の報告と, Willi (1935), Lawrence and Knutti (1934), Fuente (1949): 等の如く成熟障害なくして, 柽球生成像のみ減少 すると主張するものがある，更に極端なものとし． ては Markoff (1938), Minot (1917) 等の如く 巨核球には全く数化を認めないと稱するものもあ る.

從來，巨核球の機能に關しては栓球生成と貪喰 能のみが論じられて，而もそれ等は單に切片又は 塗抹標本による静態觀察よりの推測の域を脱しな いもので，動態觀矮を全く欠いている，栓球生 成像と云われるものに就いても，既に Schilling (1928)，Undritz(1946)が指摘した如く，巨核球周: 圍に附着せる栓球塊は穿刺血液中の栓球が凝集し て出來た人工産物に過ぎないと云い得るもので確 實な機能の表現とはならないで，われわれの行な つた巨核球の運動能の觀察こそは巨核球の機能檢 查法として最も確實なものと信ずる．前述の如く われわれの3例は剔脾前に於いてすへて極度の運 動能低下を示していたが剔脾後は㨁ちに巨核球の 運動能は正常に復歸し, 就中第 1 例, 第 2 例の如 きは健康人巨核球では稀にしか諗められない著明 な㔖起形成を示した。この突起形成は明かに程球: 
分离祖已閵係亦り，巨核球の機能元進を示すものと 考えるべきであり，營起の太さが兩侧の間で差が あるのは剔脾後の經過日稘の差によるものである うと推測する，師方術後早期に行なつた第2 例で は極度の機能九進あるものと考えられる.此の際， 更に巨核球の造動能低下乙栓球形成障害との閣係 を昭かにするには Wright (1906) の譊が參考と なる。即ち巨根球は洞内皮の間陵を逆して，その 笑起を出して血流中に烃球を分離すると考方的 るが，その時，洞内皮まで巨核球を運ぶものは， その遊走能である。從つて運動能低下は柽球生成 の減少を來たすものであううさていように剔脾 前後に明嘹な巨核球機能の差を認好たのに加え て, 患者脾㼨抽出液添加によりその巨模球の運動 能低下を示したこと注，本症患者の脾葴中に值接 巨荟球に働く催栓球減少性因子のあること確定 するに充分と信する．而して脾葴に於いて座生さ れたかっる毒性物質の作用は

1) 巨核球形成障害

2）巨核球成熟障害

3）巨核球機能障害（運動亚びに柽球分離）

4) 栓球の朁員機棈の抑制（Gerlach)

の4方面に分けられる。呴論これ等障害が常に 同程度に在るものではなく，個体によりそれぞれ 特に猞く障害される部位を異にするのは當然てあ り從つて文同じ本症であり乍ら，ある者は骨娟筑巨 核球の増加を見，ある者では迹に減少を芫るもの であろう。それはともかく本症發生機轉の主軸を なすものは骨啨巨榜球の機能の減弱にある事には 間違いない。

\section{結 語}

1）われわれは特發性栓球減少性紫琣病の慢性 型 3例を經驗し，剔脾により全例沿瘾せしめ得 た。

2) 本症の成因を追求し，患者血清及び脾抽出 液中に催栓球減少性因子の存在を認め, 次いで骨 䯈灌法實驗により本因子は直接骨髓に作用するこ とを確めた。

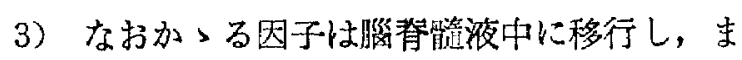

た康中にも排泄される事を認めた。

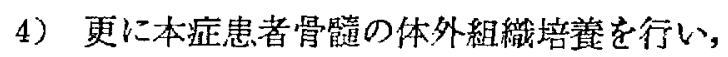
剔脾前後の三校球の機能を運動能を中心として觀 察し, 本症脾内産生の催栓球減少性因子は直接巨 校球に牊き，その機能（運動及び栓球分離）低下 を來たす事實を確認した。

5）本症剔脾後の骨骹巨核球の運動は正常人の それ以上に活欂で，榣足の他に藻明な乫起形成栓 球分触像を認め胦畫撮影に成功した。

\section{文献}

1) Dameshek, W. and Miller, E.B.: The megakaryocytes in idiopathic thrombocytopenic purpura, a form of Hypersplenism. Blood, I, 27, 1946. - 2) Frank, E.: Die essentielle Thrombopenie, (Konstitutionelle Purpura PseudoHämophilie) I. Klinisches Bild. Berl. klin. Wschr. 52, 454, 1915. II. Pathogenese. Ibid 52, $490 ， 1915$. - - 3) 福井正男：骨娟巨核球の数量測定 法主びに健康者及び諧種血液疾患に於けるその數 量, 日本內科學會雜誌, $43,291,1954$. 一4) de la Fuente, V.: Megakaryocytes in normal and in thrombocytopenic individuals, with introduction to a new system for differential count for megakaryocytes. Blood $4,614,1949 .-5$ ) Gerlach, W.: Zur Frage der Panmyelophthise. Münch. Med. Wschr. 79, 1101, 1932. -6) Harrington, W.J., Minnich, V., Hollingsworth, J. W., and Moore, C. V.: Demonstration of a thrombocytopenic factor in the blood of patients with idiopathic thrombocytopenic purpura. J. Lab. and Clin. Med. 38, 1, 1951. -7) Heilmyer, L.: Blut u. Blutkrankheiten. Handbuch der inneren Medizin, 1957. 一8) 平岡佳

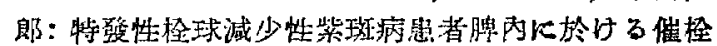
球娍少性因子に就いて，日本血没學會雑誌，16,397， 1953. -9) Kaznelson, P.: Verschwinden der hämorrhagischen Diathese bei einem Fall von "essentieller Thrombopenie" (Frank) nach Milzexstirpation. Splenogene thrombolytische Purpura. Wien. klin. Wchnschr. 29, 1451, 1916. -10) Lawrence, J.S. and Knutti, R. E.: The bone marrow in idiopathic thrombopenic purpura. Am. J.M. Sc. 188, 37, 1934. -11) Minot, G. R.: Riminished blood platelets and marrow insufficiency. A clssification and differential diagnosis of purpura hemorrhagica, aplastic anemia, and allied conditions. Arch. Int. Med. 19, 1062，1917. 一 12) 奧田邦雄, 新庄

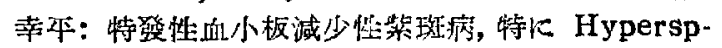




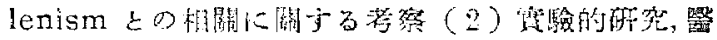
湙, ti, 580,1952. - 13) Pisciotta, A.V., Stefanini, M, and Dameshek W.: Studies on platelets. $X$. Morphologic characteristics of megaliaryocytes by phase contrast microscopy innormals and in patients with idiopathic thrombocytopenic purpura. Blood, 8, 703, 1953. -11) Rohr K.: Das menschliche Knochenmark. 1949. - 15) Seelinger, S.: Ueber Organbefund und ihre Bedeutung für die Pathogenese bei essentieller Thrombopenie und Aleukie. Klin. Wchnschr. 3,731,1924. - 16) Stefanini, M., Dameshek, W., Chatterjea, J. B., Adelson, E. and Mednicolf, I.: Studies on platelets. IX. Observations on the properties and mechanisms of action of a potent plateletagglutinin detected in the serum of a patient with idiopathic thrombocytopenic purpura
With a note on the pathogenesis of the diszase) Blood, 8, $: 6,1958,-17$ ) Troland, C.E. and Lee, F.C.: Thrombocytopen. A substance in the extract from the spleen of patients with idiopathic thrombocytopenic purpura that reduces the number of blood platelets. J.A.M.A. 111, 221, 1938. - 18) Undritz, E.: Die nicht zur Blutbildung gehörenden Zellen intravitaler Knochenmarkspunktate usw. Schweiz. Med. Wchnschr. 76, 333, 1916. - 19) Willi, H.: Uəber den Bau und die Funktion der Megakaryocyten und ihre Beziehungen zur thrombopenischen Purpura. Folia haemat. 53, 406 , 1950. - - 0 ) Wright, J, H.: Die Entstehung der Blutplättchen. Virchow's Archiv. 186, 55, 1906 .

[涭稿・畹和30年12月9日]

\title{
胃癌胃液の諸酵素に及に゙す影響について 第 3 編 胃癌胃液の肝アルギナーゼに及ばす影響
}

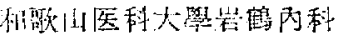 \\ 玉 证 治 鹰 \\ ON THE INFLUENCE OF CANCEROUS GASTRIC \\ JUICE UPON THE LIVER ARGINASE. \\ By \\ Haruhiko Tamaki \\ (1st Medical Clinic, Wakayama Medical Collega) \\ (Prof. R. Iwatsuru)
}

In the previous reports, I dealt with the influence of the cancerous gastric juice on the liver catalase and also on the phosphatase. The liver arginase is the subject of the present paper. The results obtained were as follows;

1. The liver arginase activity of normal rats ranged from 24.3 to 38.4 , and the average value was 31.2 .

2. The activity of the enzyme was depressed by injection of the cancerous gastric juice, indicating 17.5-25.5, average 21.4.

3. No remarkable change of arginase activity was observed when injected non cancerous gastric juice as control experiment.

4. The precipitate of cancerous gastric juice by trichloracetic acid proved arginase depressing effect, but the supernatant fluid had no effect on the enzyme. 